Contents list avaliable at Directory of Open Access Journals (DOAJ)
Aulad : Journal on Early Childhood
Vol 4 No 2 2021, Pages 136-143
ISSN : 2655-4798 (Printed); 2655-433X (Online)
Journal Homepage: https://aulad.org/index.php/aulad

\title{
Pengembangan Minat dan Bakat Anak Usia Dini Berkebutuhan Khusus
}

\author{
Yuniatari $^{1 凶}, \mathrm{Na}^{\prime} \mathrm{imah}^{1}$ \\ Pendidikan Islam Anak Usia Dini, Universitas Islam Negeri Sunan Kalijaga Yogyakarta ${ }^{(1)}$ \\ DOI: 10.31004/aulad.v4i2.117 \\ Corresponding author: \\ [19204030059@student.uin-suka.ac.id]
}

\begin{abstract}
Article Info
Abstrak

Kata kunci:

Pengembangan

Minat dan Bakat;

Anak Berkebutuhan

Khusus;

Pendidikan Anak Usia Dini.

Penelitian ini bertujuan untuk mendeskripsikan upaya yang dilakukan lembaga PAUD dalam mengembangkan minat dan bakat anak usia dini berkebutuhan khusus. Minat dan bakat ABK sangat penting dikembangkan sejak dini agar potensi yang dimiliki anak dapat dimaksimalkan sehingga dapat berguna bagi keberhasilan hidup anak di masa mendatang meskipun dengan hambatan yang dimilikinya. Penelitian ini merupakan penelitian kepustakaan, yaitu pengumpulan data menggunakan teori-teori yang relevan dengan topik penelitian. Studi pustaka meliputi proses universal seperti identifikasi teori, temuan pustaka, dan analisis dokumen. Hasil penelitian menunjukkan sekolah dan orang tua dapat mengembangkan minat dan bakat anak sesuai yang dimiliki anak. Beberapa upaya yang dapat dilakukan lembaga PAUD dalam mengembangkan minat dan bakat, yaitu identifikasi minat dan bakat anak; membangun kerjasama dengan orangtua; perhatikan kecerdasan anak; amati tingkah laku anak dan berikan stimulus; dan berikan dukungan positif pada anak.
\end{abstract}

Keywords:

Development of Interests

and Talents;

The Child with Special

Needed;

Early Chilhood Education.

\begin{abstract}
This study aims to describe the efforts made by PAUD institutions in developing the interests and talents of early childhood children with special needs. It is very important to develop the interests and talents of children with special needs from an early age so that the potential possessed by children can be maximized so that they can be useful for the success of children's lives in the future despite the obstacles they have. This research is a library research, namely collecting data using theories relevant to the research topic. Literature study includes universal processes such as identification of theories, literature findings, and document analysis. The results show that schools and parents can develop their children's interests and talents according to their own. Several efforts can be made by PAUD institutions in developing interests and talents, namely identifying children's interests and talents; build cooperation with parents; pay attention to the intelligence of the child; observe the child's behavior and provide a stimulus; and provide positive support to the child.
\end{abstract}

\section{PENDAHULUAN}

Pendidikan merupakan hak bagi setiap manusia yang dipandang sebagai persoalan paling mendasar, fundamental, dan sangat penting untuk dialami dan diperoleh setiap insan tanpa memandang latar belakang individu dan tanpa dibatasi ruang dan waktu. Deklarasi Umum Hak Asasi Manusia menegaskan bahwa setiap orang berhak 
berkesempatan memperoleh pendidikan yang sesuai dengan keahlian dan kemapuan dirinya. Persoalan ini juga didukung oleh Pemerintah Indonesia yang menekankan pentingnya pendidikan bagi semua orang dan mempercayai bahwa setiap warga negara Indonesia harus diberikan pendidikan agar mereka memiliki kebebasan untuk mengembangkan kemampuan atau potensi yang dimilikinya (PSLB, 2006). Hal ini menjadikan pendidikan dipandang sebagai salah satu upaya dalam meningkatkan kualiatas hidup manusia. Tujuan pendidikan nasional di Indonesia adalah untuk meningkatkan kualitas manusia Indonesia, yaitu manusia yang beriman dan bertakwa kepada Tuhan Yang Maha Esa, berbudi pekerti luhur, berkepribadian, mandiri, tangguh, cerdas, kreatif, terampil, disiplin, beretos kerja, profesional, bertanggung jawab, dan produktif, serta sehat jasmani dan rohani (Purwananti, 2016). Oleh sebab itu, Pemerintah berkewajiban untuk menjamin terpenuhinya hak bagi setiap warga negara dalam mendapatkan layanan pendidikan tanpa mengalami perlakuan diskriminatif dari segi apapun, baik mental, fisik,, emosional, sosial, ras, suku, budaya, golongan, dan agama. Perolehan pendidikan ini juga berlaku bagi anak yang mengalami hambatan atau yang sering kita kenal sebagai anak berkebutuhan khusus.

Anak berkebutuhan khusus (ABK) adalah insan manusia yang mempunyai kelainan atau penyimpangan yang terlihat jelas dalam proses tumbuh kembangnya dibandingkan dengan anak lain seusianya dilihat dari segi fisik, sosial emosional, mental-intelektual, sehingga membutuhkan layanan pendidikan khusus (PSLB, 2008). Anak berkebutuhan khusus memerlukan pelayanan khusus dalam kesehariannya agar potensi yang dimiliki anak dapat dimaksimalkan karena kemampuan dan potensi yang dimiliki setiap anak berbeda-beda dan bersifat unik. Sebagai insan manusia, ABK mepunyai hak yang sama seperti anak normal lainnya dalam hal memperoleh pendidikan untuk tumbuh dan berkembang di tengah-tengah keluarga, masyarakat, dan bangsa (Desiningrum, 2016). Permasalahan ini perlu diselesaikan dengan memberikan layanan pendidikan, bimbingan, dan latihan dari guru maupun orangtua untuk memahami kebutuhan dan potensi yang dimiliki anak agar dapat dikembangkan sesuai kekhususannya secara maksimal (Nugroho, 2018). Perihal ini menjadi salah satu aspek penting guna menolong anak menggapai keberhasilan hidupnya.

Anak berkebutuhan khusus dapat diklasifikasikan menjadi beberapa kelompok, antara lain: tunagrahita (gangguan mental-intelektual), kesulitan belajar, tunarungu (gangguan pendengaran), tunanetra (gangguan penglihatan), tunadaksa (gangguan anggota tubuh), tunalaras (gangguan sosial emosional), anak dengan gangguan kesehatan, dan anak berbakat (Setiawan \& Nai'mah, 2020). Selain itu, Dinie juga menambahkan jenis ABK lainnya, yaitu autisme, hiperaktif, dan indigo (Desiningrum, 2016). Karakteristik yang berbeda dan kelainan pada ABK bukan menjadi landasan pikiran bahwa mereka tidak mempunyai potensi dan kemampuan seperti minat dan bakat pada bidang-bidang tertentu. Pada dasarnya setiap insan mempunyai minat dan bakatnya masing-masing, termasuk $A B K$. Anak berkebutuhan khusus mempunyai hak yang sama seperti anak normal lainnya untuk dapat berkembang dan mencapai kesuksesan dengan berbagai minat dan bakat yang dimilikinya. Sebagai bukti nyata ada beberapa ABK yang sukses dalam mengembangkan minat dan bakatnya, seperti tokoh-tokoh ternama di dunia, yaitu Tom Cruise dan Hellen Keller. Tom Cruise adalah seorang aktor Hollywood yang terkenal. la pernah didiagnosis mengalami diseleksia atau ketidakmampuan (gangguan) dalam membaca dan menulis. Sedangkan Hellen Keller mengalami hambatan pendengaran dan penglihatan, akan tetapi ia sukses menjadi seotang penulis, dosen Amerika, dan aktivis politik (Nofiani, 2016).

Melihat dua kisah tersebut jika terjadi di lingkungan masyarakat, mungkin mereka akan mengira ABK hanyalah orang yang bodoh yang tidak dapat melakukan apa-apa. Anak yang memiliki keterbatasan akan dipandang sebelah mata oleh masyarakat, akan dianggap tidak mempunyai kemampuan, kecerdasan dan potensi lemah atau pendapat lainnya, anak akan semakin dang kurang memiliki masa depan yang cerah, lebih parah lagi anak akan dianggap sebagai anak yang hanya bisa merepotkan kedepannya (Sugiarto, 2018). Berdasakan hasil penelitian yang dilakukan oleh Ankarlina, dkk., mengungkapkan bahwa rata-rata orang tua ABK menyekolahkan anaknya karena tuntuntan lingkungan tempat tinggalnya, dimana anak-anak pada lingkungan tempatnya tinggal merupakan anak yang mengenyam pendidikan dengan pergi ke sekolah. Terlepas dari adanya harapan, cita-cita dan tujuan yang ingin dicapai, mereka mengakui bahwa mereka menyekolahkan anaknya yang berkebutuhan khusus agar label "anak bodoh", "anak tidak sekolah" tidak melekat pada diri anak mereka. Rata-rata orang tua ABK melakukan hal itu agar mendapat pengakuan dari lingkungannya bahwa meskipun anaknya berkebutuhan khusus namun anak tersebut tetap harus mengenyam pendidikan (Primadata et al., 2015). Namun, pada kenyataanya dengan minat dan bakat yang ada pada ABK bisa menjadikan mereka sebagai sosok yang luar biasa dan mampu menarik perhatian dunia. Bukti lain datang dari Indonesia melalui pengalaman Munib Chatib. Ia mempunyai anak yang mengalami discalculia atau hambatan dalam menghitung. Meskipun anaknya sulit menghitung, namun Chatib berhasil membuat anaknya mahir dalam menciptakan berbagai puisi (Chatib, 2014). Kisah lain yang membanggakan nama Indonesia datang dari ABK yang berhasil memenangkan 13 perak, 15 medali emas, dan 11 perunggu melalui Olimpiade Tunagrahita di Athena pada Juli 2011 (Mudjito, 2013).

Dari berbagai data tersebut menunjukkan bahwa ABK dengan hambatan yang dimilikinya juga mempunyai potensi bakatnya masing-masing dan mereka akan mampu mencapai tingkat kesuksesan apabila potensi tersebut dimaksimalkan, baik penanganan dari orang tua, guru, sekolah, dan masyarakat. Seperti yang diungkapkan Dinie R. $\mathrm{D}$, supaya $\mathrm{ABK}$ dapat berkembang secara optimal, maka mereka membutuhkan sosok orang tua atau caregiver yang penyayang dan tangguh (Desiningrum, 2016). Dalam mengembangkan minat dan bakat yang dimiliki ABK, maka 
sangat penting adanya penangan yang tepat pada ABK. Dalam penelitiannya Ahmad Atabik mengungkapkan bahwa tujuan dari pengembangan minat dan bakat yang dimiliki anak supaya anak bisa belajar dan pada masa mendatang ia dapat bekerja di bidang yang diminatinya sesuai dengan kemampuan anak (Atabik, 2018).

Berbagai minat dan bakat yang dimiliki ABK lebih baik ditanamkan dan dikembangkan sejak usia dini. Pada usia dini, anak mengalami masa peka yang mana anak mulai sensitif dalam menerima berbagai upaya pengembangan seluruh potensi yang dimilikinya. Oleh karena itu, idealnya ABK dapat disekolahkan di lembaga Pendidikan Anak Usia Dini (PAUD). Pendidikan Anak Usia Dini adalah salah satu upaya pembinaan dan rangsangan pendidikan yang diberikan pada anak sejak lahir hingga umur 6 tahun untuk membantu tumbuh kembang anak secara jasmani dan rohani agar anak lebih siap dalam mnjalani tingkat pendidikan selanjutnya. Pendidikan Anak Usia Dini bertujuan untuk membantu mengembangkan seluruh kemampuan dan potensi intelektual, fisik, agama, moral, sosial, dan emosional dalam lingkungan pendidikan yang demokratis dan kondusif secara optimal (RI, 2016). Bentuk langkah nyata yang dilakukan Pemerintah dalam memberikan layanan pendidikan bagi ABK setidaknya terdiri dari dua sistem, yaitu sekolah khusus dan sistem regresi, seperti Sekolah Luar Biasa dan Sekolah Inklusi (Masnipal, 2013). Sekolah luar biasa (SLB) adalah sekolah yang menyediakan fasilitas pendidikan khusus untuk anak-anak yang memiliki perbedaan kemampuan (ABK) disesuaikan dengan derajat dan jenis kebutuhan khusus anak. Sedangkan sekolah inklusi adalah salah satu bentuk pemerataan dan bentuk perwujudan pendidikan tanpa diskriminasi dimana anak berkebutuhan khusus dan anak-anak pada umumnya dapat memperoleh pendidikan yang sama. Pendidikan inklusi merupakan bentuk pelayanan pendidikan khusus yang mensyaratkan agar semua anak berkebutuhan khusus dapat menerima pendidikan yang setara di kelas reguler bersama teman-teman seusianya (Darma \& Rusyidi, 2015). Pendidikan inklusif merupakan sistem layanan pendidikan yang memberikan kesempatan kepada semua anak untuk belajar bersama-sama di sekolah umum dengan memperhatikan keragaman dan kebutuhan individual, sehingga potensi anak dapat berkembang secara optimal (Rachmayana, 2013). Oleh karena itu, penyelenggaraan pendidikan bagi anak usia dini yang memliki kebutuhan khusus dapat disekolahkan di lembaga PAUD luar biasa maupun PAUD inklusif.

Bloom mengatakan bahwa jika seorang anak diperlakukan secara benar, maka anak tersebut dapat berkembang dan hidup lebih baik, serta berpikir lebih cemerlang. Oleh sebab itu, masa kanak-kanak disebut sebagai masa golden age karena pada masa ini sangat penting untuk menstimulasi pertumbuhan otak anak dengan memberikan layanan pendidikan, memberikan perhatian terhadap kesehatan anak, dan menyediakan gizi yang cukup (Musbikin, 2010). Pada dasarnya minat dan bakat ABK sangat penting dibangun dan dikembangkan dari sejak dini. minat adalah rasa ketertarikan, perhatian, keinginan lebih yang dimiliki seseorang terhadap suatu hal, tanpa ada dorongan (Syardiansah, 2016). Sedangkan bakat adalah kemampuan bawaan sebagai potensi yang masih perlu dikembangkan dan dilatih agar dapat terwujud (Hanafie \& Amin, 2018). Pengembangan minat dan bakat ini bertujuan agar anak-anak memiliki ketertarikan pada suatu hal yang kemudian dapat dikembangkan secara optimal dan maksimal. Selain itu, ABK juga harus memiliki kemampuan dan dan keahlian dalam menghasilkan sesuatu agar mereka tidak lagi dipandang sebelah mata oleh masyarakat. Oleh karena itu, minat dan bakat ABK sangat perlu dikembangkan untuk bekal mereka di masa yang akan datang. Berdasarkan beberapa pemaparan yang telah dijabarkan, maka penelitian ini bertujuan untuk mendeskripsikan upaya yang dilakukan lembaga PAUD dalam mengembangkan minat dan bakat anak usia dini berkebutuhan khusus.

\section{METODE}

Penelitian ini merupakan penelitian studi pustaka, yaitu kegiatan penelitian dilakukan dengan cara mengumpulkan data yang berkaitan dengan masalah penelitian yang didapat dari sumber-sumber buku referensi, hasil penelitian sebelumnya yang relevan, catatan, artikel, serta berbagai jurnal. Kegiatan penelitian dilakukan dengan cara pengumpulan, pengolahan, dan penyimpulan data dengan metode tertentu guna menemukan jawaban yang berkaitan dengan topik penelitian (Sari \& Asmendri, 2018). Menurut Nazir (2011), studi kepustakaan adalah metode pengumpulan data dan informasi dengan mengadakan riset penelaahan terhadap literatur-literatur, seperti buku, catatan, laporan yang berhubungan dengan permasalahan yang dipecahkan. Dalam pencarian teori, peneliti hendak mengumpulkan data sebanyak-banyaknya dari kepustakaan yang berhubungan. Sumber-sumber kepustakaan dapat diperoleh dari buku, majalah, jurnal, hasil-hasil riset sebelumnya, dan sumber-sumber lain yang relevan. Oleh karena itu, studi pustaka meliputi proses universal seperti identifikasi teori, temuan pustaka, dan analisis dokumen yang berisikan informasi yang relevan dengan topik masalah penelitian.

\section{HASIL DAN PEMBAHASAN}

\section{Minat dan Bakat Anak Berkebutuhan Khusus}

Lembaga PAUD dan orang tua harus mengembangkan minat dan bakat anak agar potensi yang dimiliki anak dapat dimaksimalkan dan tersalurkan dengan baik untuk mecapai keberhasilan hidup ABK di masa mendatang. Anak yang memiliki bakat akan memungkinkan mereka mampu mencapai prestasi di bidang tertentu, tidak terkecuali ABK yang mengalami hambatan. Agar prestasi ini dapat terwujud, maka bakat perlu dikembangkan dengan memberi pengetahuan, latihan, motivasi, dan pengalaman kepada anak (Djamarah, 2002). Sebagaimana yang telah penulis paparkan di atas bahwa ABK adalah anak yang memiliki kelainan atau penyimpangan yang terlihat jelas dalam 
proses tumbuh kembangnya dibandingkan dengan anak lain seusianya dilihat dari segi fisik, sosial emosional, mental-intelektual, sehingga membutuhkan layanan pendidikan khusus.

Minat adalah suatu perasaan yang menunjukkan rasa suka yang lebih atau merasa tertarik pada suatu hal atau aktivitas tanpa adanya paksaan dari siapapun atau dari luar diri (Slameto, 2010). Minat berhubungan dengan sesuatu yang menguntungkan dan memberikan rasa kepuasan pada diri individu. Kesenangan ini bersifat sementara maupun bersifat tetap. Minat bisa bersifat tetap apabila terdapat unsur dalam memenuhi kebutuhan individu dan memberi kepuasan. Apabila minat sering diekspresikan, maka semakin kuat minat tersebut. Dan sebaliknya minat akan menjadi pupus apabila tidak ada kesempatan untuk mengekspresikannya (Jahja, 2011).

Bakat adalah kemampuan bawaan atau potensi istimewa yang perlu dikembangkan dan dilatih. Pada dasarnya, terdapat bakat yang dimiliki setiap manusia dengan kualitas yang berbeda-beda dalam bidang tertentu. Bakat yang dimiliki ini memungkinkan individu mampu mencapai prestasi pada bidang tertentu. Hal ini memerlukan adanya pemberian pengetahuan, latihan, dorongan asosiasi dan moral dari lingkungan terdekat. Setiap anak memiliki bakat yang berbeda-beda, dapat bersifat akademik dan non akademik. Bakat yang bersifat akademik berhubungan dengan pelajaran, sedangkan bakat bersifat non akademik berhubungan dengan bidang seni, sosial, olahraga, dan kepemimpinan (Jahja, 2011).

Terdapat beberapa macam minat dan bakat yang dimiliki oleh setiap individu yang dapat dikembangkan, seperti terlihat pada tabel 1.

\section{Tabel 1. Macam-Macam Minat dan Bakat}

\begin{tabular}{|c|c|c|}
\hline No & Minat (Susanto, 2014) & Bakat (Ali \& Asrori, 2006) \\
\hline 1. & $\begin{array}{l}\text { Minat terhadap alam sekitar (berkaitan dengan } \\
\text { tumbuhan, binatang, dan alam) }\end{array}$ & $\begin{array}{l}\text { Bakat akademik khusus (berhubungan dengan } \\
\text { aktivitas mengolah angka, logika, bahasa, dan } \\
\text { sejenisnya) }\end{array}$ \\
\hline 2. & $\begin{array}{l}\text { Minat hitung-hitungan (berkaitan dengan } \\
\text { aktivitas menghitung) }\end{array}$ & $\begin{array}{l}\text { Bakat seni (berhubungan dengan aktivitas seni, } \\
\text { contoh bakat seni musik mampu memainkan } \\
\text { menciptakan lagu, dan sebagainya) }\end{array}$ \\
\hline 3. & $\begin{array}{l}\text { Minat terhadap ilmu pengetahuan (berkaitan } \\
\text { dengan aktivitas memecahkan permasalahan } \\
\text { dan menemukan fakta baru) }\end{array}$ & $\begin{array}{l}\text { Bakat kreatif-produktif (berhubungan dengan } \\
\text { aktivitas menciptakan sesuatu yang baru, inovatif, } \\
\text { dan dapat dimanfaatkan untuk kepentingan umum) }\end{array}$ \\
\hline 4. & $\begin{array}{l}\text { Minat terhadap mekanis (berkaitan dengan } \\
\text { mesin-mesin atau alat mekanik) }\end{array}$ & $\begin{array}{l}\text { Bakat kinestetik atau psikomotorik (berhubungan } \\
\text { dengan aktivitas gerak dan olahraga) }\end{array}$ \\
\hline 5. & $\begin{array}{l}\text { Minat persuasif (berkaitan dengan aktivitas } \\
\text { yang mampu mempengaruhi orang lain) }\end{array}$ & $\begin{array}{l}\text { Bakat sosial (berkaitan dengan aktivitas hubungan } \\
\text { sosial, seperti menwarkan produk, bernegosiasi, } \\
\text { dan lain-lain) }\end{array}$ \\
\hline 6. & $\begin{array}{l}\text { Minat seni (berkaitan dengan kerajinan, kreasi } \\
\text { tangan, dan kesenian) }\end{array}$ & \\
\hline 7. & $\begin{array}{l}\text { Minat musik (berkaitan dengan aktivitas } \\
\text { bermusik, seperti menonton konser, menyanyi, } \\
\text { dan memainkan alat-alat musik) }\end{array}$ & \\
\hline 8. & $\begin{array}{l}\text { Minat klerikal (berkaitan dengan pekerjaan } \\
\text { administratif) }\end{array}$ & \\
\hline 9. & $\begin{array}{l}\text { Minat laterer (berkaitan dengan aktivitas } \\
\text { menulis dan membaca karangan) }\end{array}$ & \\
\hline 10. & $\begin{array}{l}\text { Minat layanan sosial (bekaitan dengan aktivitas } \\
\text { yang menyukai membantu orang lain. }\end{array}$ & \\
\hline
\end{tabular}

Tabel 1 menunjukkan bahwa minat dan bakat yang dimiliki anak akan berbeda antara satu dengan yang lainya. Oleh karena itu, sebagai orang tua dan pendidik di sekolah yang baik perlu memperhatikan dan mengembangkan minat dan bakat yang ada pada dalam diri anak tanpa memaksakan kehendak atau keinginan orang tua. Setiap anak berpotensi cerdas apabila dikembangkan sesuai dengan minat dan bakat yang dimilikinya. Anak yang cerdas bukan hanya anak yang ppandai berhitung atau matematika. Anak yang pandai mengeskpresikan diri di bidang seni, olahraga, dan lain-lain juga termasuk anak yang cerdas.

\section{Upaya Mengembangkan Minat dan Bakat Anak Usia Dini Berkebutuhan Khusus}

Setiap anak yang lahir di dunia memiliki potensi yang berbeda-beda, mereka akan memiliki kecerdasan dan bakat yang berbeda antara anak satu dan anak lainnya. Sudah seharusnya sebagai orang tua atau masyarakat tidak menyamaratakan dan membanding-bandingkan antara anak yang satu dengan yang lainnnya. Sebaliknya kita sebagaai orang tua harus mengerti kekurangan, keterbatasan dan keistimewaan yang dimiliki anak sejak dini, baik dari segi fisik maupun psikis. Keterbatasan pada anak tersebut menyebabkan orangtua kurang mengerti dengan potensi yang dimiliki anak, hampir semua orang tua menginginkan anaknya sempurna baik dari segi fisik psikis dan 
akademiknya (Sugiarto, 2018). Agar potensi yang dimiliki anak ini dapat dimaksimalkan sejak dini, maka orang tua dapat mempercayakan anaknya yang berkebutuhan khusus untuk dimasukkan dalam lembaga PAUD. Dalam mengembangkan minat dan bakat anak usia dini yang memiliki kebutuhan khusus, terdapat beberapa upaya yang dapat dilakukan oleh lembaga PAUD. Upaya pengembangan minat dan bakat ini merupakan upaya-upaya umum yang dapat diterapkan untuk semua jenis ABK yang ada di PAUD. Upaya-upaya yang dapat dilakukan oleh lembaga PAUD dalam mengembangkan minat dan bakat anak usia dini berkebutuhan khusus, seperti sebagai berikut:

Pertama, Identifikasi Minat dan Bakat Anak. Hal penting yang perlu dilakukan terkait minat dan bakat anak adalah melakukan proses identifikasi. Proses identifikasi minat dan bakat anak sangat penting dilakukan sejak usia dini. Guru dapat memberikan bimbingan dan intervensi secara khusus jika anak telah mengetahui potensi minat dan bakat yang dimiliki anak sejak dini (Jaya et al., 2018). Proses identifikasi ini dapat dilakukan dengan melakukan asesmen pada anak. Sekolah dapat meminta bantuan ahli seperti psikolog atau dokter anak untuk dapat memberikan tes minat bakat kepada anak. Selain itu, sekolah juga dapat melakukan asesmen dengan mengunjungi rumah anak. Dalam hal ini, sekolah dapat mengutus guru pendamping khusus untuk mengunjungi rumah anak dengan melakukan wawancara kepada orang tua dan keluarga yang tinggal bersama ABK terkait minat dan bakat yang sudah ditemukan oleh orang tua. Guru juga bisa bertanya tentang aktivitas sehari-hari yang sering dilakukan anak dan media belajar yang tersedia di rumah (Sri Wahyuni et al., 2020).

Kedua, Membangun Kerjasama dengan Orang Tua. Anak berkebutuhan khusus yang telah teridentifikasi sejak kecil dan orang tuanya sudah memiliki kesadaran dalam melakukan pendampingan khusus pada anaknya, maka kekhususan yang dimiliki anak ini dapat ditanggulangi sejak dini. Dalam hal ini, peran orang tua dalam menerima dan mendampingi anak sangat dibuthkan. Sekolah hanya sebagai media yang dipilih orang tua untuk membantu anak dalam mengembangkan potensinya dan orang tualah sebagai penentu keputusan apakah anak perlu diberi pembinaan atau tidak. Orang tua yang memahami bahwa ABK harus mendapatkan layanan pendidikan dan memilih sekolah yang menyediakan layanan khusus merupakan salah satu faktor penting dalam upaya pengembangan minat dan bakat anak. Selain itu, orang tua yang memahami bahwa anaknya membutuhkan pendampingan khusus akan memberikan kesempatan pada anak agar minat dan bakatnya yang telah teridentifikasi dapat dikembangkan oleh sekolah secara maksimal (Sri Wahyuni et al., 2020). Keterlibatan orang tua dalam proses pembelajaran anak mempunyai peranan penting sebagai motivasi dan anak akan merasa didukung oleh orang tuanya. Oleh karena itu, orang tua tidak boleh memaksakan kehendak kepada anak terkait dengan minat dan bakat yang tidak dimiliki anak (Graha, 2020). Anak hanya perlu mendapatkan dorongan sesuai dengan minat dan bakatnya. Dalam mengembangkan minat dan bakat anak, guru harus mampu memeberikan stimulasi yang sesuai dengan minat dan bakat yang telah teridentifikasi agar anak dapat tumbuh dan berkembang secara optimal tanpa adanya paksaan (Anggraini et al., 2020).

Ketiga, Perhatikan Kecerdasan Anak. Pola pikir perlu ditanamkan kepada setiap orang bahwa semua anak adalah cerdas, tidak ada anak yang tidak cerdas, meskipun anak tersebut merupakan anak berkebutuhan khusus. Setidaknya ada delapan kecerdasan yang dimiliki anak yang bisa kita sebut sebagai kecerdasan majemuk (multiple intelligence). Kecerdasan majemuk ini dipelopori oleh Howard Gardner. Howard memandang kecerdasan tidak bersifat mono, misalnya kerdasan kognitif saja, tetapi lebih kepada membagi kecerdasan menjadi beberapa bagian. Sangat penting bagi lembaga PAUD untuk menyadari bahwa minat dan bakat yang dimiliki setiap anak berbeda antara dengan yang lainnya. Oleh karena itu, lembaga PAUD wajib bertugas dalam mengakomodir setiap kebutuhan ABK sesuai minat dan bakat yang dimilikinya. Delapan jenis kecerdasan ini, yaitu: kecerdasan linguistik, kecerdasan matematis-logis, kecerdasan kinestetik, kecerdasan spasial, kecerdasan interpersonal, kecerdasan intrapersonal, kecerdasan musikalis, dan kecerdasan naturalis (Amstrong, 2003). Teori kecerdasan majemuk ini dapat dijadikan acuan bagi lembaga PAUD untuk mengembangkan minat dan bakat anak. Bisa saja ada seorang anak tidak pandai dalam aktivitas menghitung, tetapi sangat lincah dan handal dalam aktivitas kinestetik dan olah tubuhnya, sehingga dapat teridentifikasi bahwa anak ini sangat berbakat di bidang olahraga (Harususilo, 2018). Contoh lainnya, bisa saja ada seorang $A B K$ yang pandai menyanyi dan menyukai musik, maka bisa dikatakan ia berbakat di bidang musikalis.

Keempat, Amati Tingkah Laku Anak dan Berikan Stimulus. Lembaga PAUD perlu mengamati tingkah laku anak dari berbagai jenis kegiatan yang telah dijalankan anak. Dari kegiatan itu, guru dapat melihat aktivitas apa saja yang membuat anak senang, merasa tertarik, dan ingin melakukan kegiatan berulang kali sehingga anak selalu ingin tahu lebih banyak hal. Guru juga dapat memberikan stimulus pada anak agar mereka lebih mampu bereksplorasi terhadap diri dan lingkungan. Lembaga PAUD dapat memberi kesempatan pada amak dalam mengenal berbagai bentuk kegiatan, seperti olahraga, musik, dan berbagai aktivitas lain yang bisa dilakukan di sekolah (Harususilo, 2018). Sebagai contoh, guru dapat mengajak anak untuk senam bersama, menari, bernyanyi, dan mengenal lingkungan sekitar. Selain itu untuk mengembangkan minat dan bakat anak, guru juga dapat meminta anak untuk berani unjuk diri di depan kelas tanpa harus merasa minder dengan teman lainnya.

Kelima, Beri Dukungan Positif pada Anak. Sekolah harus mampu menghargai setiap usaha yang telah di lakukan anak. Baik sekolah, keluarga, dan lingkungan sekitar memiliki peran yang besar dalam mengembangkan minat dan bakat ABK sejak usia dini. Dukungan positif sangat dibutuhkan anak agar potensi yang dimiliki anak dapat dikembangkan secara maksimal dan optimal. Bentuk dukungan positif ini bukan hanya dihitung dari sekedar materi, tetapi adanya perhatian dan waktu yang diberikan oleh sekolah dan guru. Beri pujian dan apresiasikan setiap 
aktivitas kegiatan yang telah berhasil dilakukan anak. Hal ini sangat berpengaruh dalam meberikan dukungan kepada anak agar mereka dapat mengembangkan minat dan bakatnya dengan perasaan senang (Harususilo, 2018).

\section{KESIMPULAN}

Pengembangan minat dan bakat ABK sejak usia dini sangat penting dilakukan oleh sekolah dan orangtua agar potensi yang dimiliki anak dapat dimaksimalkan sehingga hal ini dapat berguna bagi keberhasilan hidup ABK di masa yang akan datang. Beragam minat dan bakat yang dimiliki anak antara satu dengan yang lainnya akan berbeda, sehingga sekolah dapat mengembangkan minat dan bakat sesuai kehendak anak. Ada berbagai upaya yang dapat dilakukan lembaga PAUD dalam mengembangkan minat dan bakat $A B K$, yaitu: 1) identifikasi minat dan bakat; 2 ) membangun kerjasama dengan orangtua; 3) perhatikan kecerdasan; 4) amati tingkah laku dan berikan stimulus; dan 5) berikan dukungan positif.

\section{UCAPAN TERIMA KASIH}

Penulis mengucapkan terima kasih banyak kepada semua pihak yang sudah ikut terlibat dalam penyelesaian artikel jurnal ini sehingga dapat dipublikasikan.

\section{DAFTAR PUSTAKA}

Ali, M., \& Asrori, M. (2006). Psikologi Remaja. Sinar Grafika Offset.

Amstrong, T. (2003). Sekolah Para Juara: Menerapkan Teori Multiple Intelligences di Dunia Pendidika. Kaifa.

Anggraini, I. A., Utami, W. D., \& Rahma, S. B. (2020). Mengidentifikasi Minat Bakat Siswa Sejak Usia Dini di SD Adiwiyata. Islamika, 2(1), 161-169. https://doi.org/10.36088/islamika.v2i1.570

Atabik, A. (2018). Pendidikan Dan Pengembangan Potensi Anak Usia Dini. ThufuLA: Jurnal Inovasi Pendidikan Guru Raudhatul Athfal, 2(1), 149. https://doi.org/10.21043/thufula.v2i1.4270

Chatib, M. (2014). Orangtuanya Manusia. Kaifa.

Darma, I. P., \& Rusyidi, B. (2015). Pelaksanaan Sekolah Inklusi di Indonesia. Prosiding Penelitian Dan Pengabdian Kepada Masyarakat, 2(2). https://doi.org/10.24198/jppm.v2i2.13530

Desiningrum, D. R. (2016). Psikologi Anak Berkebutuhan Khusus. Psokosain.

Djamarah, S. B. (2002). Psikologi Belajar. Rineka Cipta.

Graha, G. K. (2020). Kenali Minat dan Bakat Anak Sejak Dini. BP PAUD Dan DIKMAS D.I. Yogyakrta. https://pauddikmasdiy.kemdikbud.go.id/berita/kenali-minat-dan-bakat-anak-sejak-dini/

Hanafie, N. K., \& Amin, F. H. (2018). Bakat Dan Kreativitas Pembelajar. Prosiding Seminar Nasional, 4(1), 334-343. http://www.journal.uncp.ac.id/index.php/proceding/article/view/1317/1136\%0Ahttp://www.journal.unc p.ac.id/index.php/proceding/article/view/1317

Harususilo, Y. E. (2018). Ini Dia, 5 Tahap Mengenali dan Mengembangkan Minat Bakat Anak. Kompas.Com. https://edukasi.kompas.com/read/2018/09/04/19270871/ini-dia-5-tahap-mengenali-danmengembangkan-minat-bakat-anak?page=all.

Jahja, Y. (2011). Psikologi Perkembangan. Kencana.

Jaya, H., Haryoko, S., Saharuddin, Suhaeb, S., Sabran, \& Mantasia. (2018). Life Skills Education for Children with Special Needs in order to Facilitate Vocational Skills. Journal of Physics: Conference Series, 1028(1). https://doi.org/10.1088/1742-6596/1028/1/012078

Masnipal. (2013). Siap Menjadi Guru dan Pengelola PAUD Profesional. PT Elex Media Komputindo.

Mudjito. (2013). Mengembangkan Bakat-bakat Istimewa Anak Berkebutuhan Khusus. Kompas.Com. https://edukasi.kompas.com/read/2013/10/23/1320004/mengembangkan-bakat-bakat-istimewa-anakberkebutuhan-khusus

Musbikin, I. (2010). Buku Pintar PAUD: Dalam Perspektif Islami. Laksana.

Nazir, M. (2011). Metode Penelitian. Ghalia Indonesia.

Nofiani, E. (2016). Pembinaan Minat dan Bakat Anak Berkebutuhan Khusus (ABK) (Studi Deskriptif di Sekolah Dasar Inklusi). Prosiding Seminar Nasional Reforming Pedagogy, 9-14.

Nugroho, K. P. A. D. R. S. (2018). Gaya Hidup Yang Memengaruhi Kesehatan Anak Berkebutuhan Khusus di SLB Negeri Salatiga. Jurnal Keperawatan Muhammadiyah, 2(2). https://doi.org/10.30651/jkm.v2i2.1069

Primadata, A. P., Soemanto, R., \& Haryono, B. (2015). Tindakan Orangtua dalam Menyekolahkan Anak Berkebutuhan Khusus pada Layanan Pendidikan Inklusif di Sekolah Dasar Negeri 1 Tanjung, Kecamatan Purwokerto Selatan, Kota Purwokerto. Jurnal Analisa Sosiologi, 4(1).

PSLB, D. (2006). Pedoman Administrasi Sekolah Menengah Pertama Luar Biasa. Depdiknas.

PSLB, D. (2008). Pedoman Pelaksanaan Manajemen SLB Tunagrahita (C): Program Pendidikan Menengah. Depdiknas.

Purwananti, Y. S. (2016). Peningkatan Kualitas Pendidikan Sebagai Pencetak Sumber Daya Manusia Handal. Proceedings International Seminar FoE (Faculty of Education), 1, 220-229.

Rachmayana, D. (2013). Diantara Pendidikan Luar Biasa Menuju Anak Masa Depan yang Inklusif. Luxima.

RI, K. (2016). Memahami Pendidikan Anak Usia Dini. Dirjen PAUD Dan Dikmas. http://paud.kemdikbud.go.id/2016/03/30/memahami-pendidikan-anak-usia-dini/ 
Sari, M., \& Asmendri. (2018). Penelitian Kepustakaan (Library Research) dalam Penelitian Pendidikan IPA. Penelitian Kepustakaan (Library Research) Dalam Penelitian Pendidikan IPA, 2(1), 15. https://ejournal.uinib.ac.id/jurnal/index.php/naturalscience/article/view/1555/1159

Setiawan, F. A., \& Nai'mah. (2020). Mengenal Konsep-Konsep Anak Berkebutuhan Khusus Dalam PAUD. Jurnal Program Studi PGRA, 6(2), 193-208. https://jurnal.stitnualhikmah.ac.id/index.php/seling/article/view/635

Slameto. (2010). Belajar dan Faktor-Faktor yang Mempengaruhi. Rineka Cipta.

Sri Wahyuni, F., Hufad, A., Supriatna, S., \& Studi Pendidikan Sosiologi, P. (2020). Program Unjuk Bakat Bagi Siswa $\begin{array}{lllll}\text { Berkebutuhan } & \text { Khusus } & \text { Di } & \text { Sekolah } & \text { Inklusi. }\end{array}$ https://unisbank.ac.id/ojs/index.php/sendi_u/article/view/8062/3031

Sugiarto. (2018). Mengenal Anak Berkebutuhan Khusus (ABK). BPPAUD Dan Dikmas Kalbar. https://pauddikmaskalbar.kemdikbud.go.id/berita/mengenal-anak-berkebutuhan-khusus.html

Susanto, A. (2014). Teori Belajar dan Pembelajaran di SD. Kencana Prenadamedia Group.

Syardiansah. (2016). Hubungan Motivasi Belajar dan Minat Belajar terhadap Prestasi Belajar Mahasiswa Mata Kuliah Pengantar Manajemen. Manajemen Dan Keuangan, 5(1), 243. 